\title{
Effect of Different Land Use on Soil Physical Properties of Experimental Farms of NDUAT, Ayodhya
}

\author{
Bhanu Pratap Singh ${ }^{1}$, SFA Zaidi ${ }^{1}$, Santosh Kumar Singh ${ }^{2 *}$ and Aradhna Kumari ${ }^{3}$ \\ ${ }^{1}$ Department of Soil Science and Agricultural Chemistry, Acharya Narendra Deva University of Agriculture and Technology, \\ Faizabad, Uttar Pradesh, India \\ ${ }^{2}$ Department of Soil Science, Dr. Rajendra Prasad Central Agricultural University, Pusa, Bihar, India \\ ${ }^{3}$ College of Agriculture, JNKVV, Ganj Basoda, Madhya Pradesh, India
}

*Corresponding author: santoshraupusa@gmail.com

Received: $13-09-2019$

Revised: $25-10-2020$

Accepted: 29-11-2020

\begin{abstract}
A field and laboratory studies were conducted to assess the physical properties of different land-use of the main experimental farms of N.D. University of Agriculture \& Technology, Kumarganj, Faizabad (U.P.) covering about 72.0 hectares. The soils samples were collected under cropland use (CLU), plantation land use (PLU), forest land use (FLU), barren land use (BLU) and grassland use (GLU) from 76 georeferenced points. The sampling was done twice one in the month of July (kharif) and another in the month of January (Rabi). From the study, it was revealed that among different CLU, legume-based cropping system (LBCS) had the maximum saturated hydraulic conductivity (SHC) of $0.26 \mathrm{~cm} \mathrm{hr}^{-1}$. However, the lowest bulk density was observed in vegetable-based cropping system (VBCS) for both the season. Similarly, in plantation land use the Bael orchard had the highest SHC of $0.21 \mathrm{~cm} \mathrm{hr}^{-1}$ but the lowest bulk density was observed in mango orchard for both the seasons signifying the highest amount of litter fall as compared to other plantation type. In case of FLU the highest value for SHC was observed in Eucalyptus spp. forest $\left(0.19 \mathrm{~cm} \mathrm{hr}^{-1}\right)$ however in this case the bulk density values were comparable with each other. The barren and grass land use had the lowest SHC and highest bulk density values. The soil temperature under different land use decreased with increasing soil depth in May and increased with increasing depth in January. These soil properties were suited to plant for survival in large gap of temperature overall the year, i.e., about $10^{\circ} \mathrm{C}$ to $36^{\circ} \mathrm{C}$.
\end{abstract}

Keywords: Cropland, forest, grassland, land use, physical properties

Soil is a component of the lithosphere and biosphere system. It is a vital natural resource on which the supporting life system and socio-economic development depend. The soil, water, climate, flora and fauna constitute the basic natural resources and the national treasure of any country. The soil is the most important among them. It is the basic source to produce food, fodder, feed, fuel and fibre - the necessities of the human being. The agriculture and the other allied activities are changing the prosperity and economic growth of a country, which depends on the soil resource. The land is a gift given by nature to mankind; hence it is the basic resource of human society. Land use is the surface utilization of all developed and vacant land on a specific point at a given time and space. Soil productivity and sustainability depend on the dynamic equilibrium among its physical, chemical and biological properties. These properties are continuously influenced by land uses with propound influence on soil properties and thus, help in the restoration of soil quality.

\footnotetext{
How to cite this article: Singh, B.P., Zaidi, SFA., Singh, S.K. and Kumari, A. (2020). Effect of Different Land Use on Soil Physical Properties of Experimental Farms of NDUAT, Ayodhya. International Journal of Bioresource Science, 7(2): 87-91.
}

Source of Support: None; Conflict of Interest: None

๔ 
One of the prime prerequisites for better use of land is information on existing land use patterns and changes in land use through time. Land use patterns of an area or a region is an important aspect in the context of sustainable agriculture production, particularly for the arid region where sparse and high variation in diurnal temperature, high evaporation and low humidity, the alluvial landforms have resulted to the variability in agroclimatic conditions which requires site-specific management practices for future agriculture.

Land use of Kumarganj may be divided into five major land use categories, i.e. (1) Area under cropland, (2) Area under plantation land, (3) Area under forest, (4) Area under grassland and (5) Area under Barren land. Despite the significant growth in production, the sustainability of some cropping systems is not being maintained. Therefore, a comprehensive account of our land resources ascertaining its potential and problems towards optimizing land use on a sustainable basis is necessary.

\section{MATERIALS AND METHODS}

The investigation was carried out at experiment farms of NDUA\&T Kumarganj, Faizabad (U.P.). The Farm is located at a distance of $42 \mathrm{~km}$ from Faizabad city on Faizabad - Raibareli road and situated at $26^{\circ} 32^{\prime} \mathrm{N}$ latitude, $81^{\circ} 49^{\prime} \mathrm{E}$ longitude and at an altitude of 113.0 meters from the mean sea level. The soils are confined to the alluvial belt whose geology is dominated by alluvium deposits from the Gomati and Ghaghara rivers where slope gradients are almost negligible. The area falls under the subtropical zone, which is characterized by hot and dry summers and cold winters. The temperature in summer reaches up to $45^{\circ} \mathrm{C}$ with desiccating winds, and in winter it goes down to $5{ }^{\circ} \mathrm{C}$. The potential evaporation is very high from March to October. In this tract, rains are received from the south-west monsoon. The average rainfall is about $1070 \mathrm{~mm}$ and about $85 \%$ of which is received during the rainy season.

The total number of selected land use is nineteen (Table 1). Four soil samples were collected from each land use about $0-15 \mathrm{~cm}$ depth with the help of Auger and Khurpi. In all 76 samples, 12 from cropland use, 16 from plantation land use, 16 from forest land use and 16-16 from barren and grassland use respectively were with GPS location.

Table 1: Details of the location under different land use

\begin{tabular}{lll}
\hline Treatment/Land use & \multicolumn{2}{l}{ GPS Locations } \\
\hline 1. Cropland & Longitude & Latitude \\
\hline $\begin{array}{l}\text { (a) Rice-Wheat Cropping } \\
\quad \text { System (RWCS) }\end{array}$ & 26.545131 & 81.837746 \\
(b) Legume based Cropping & 26.535075 & 81.837053 \\
$\quad$ System (LBCS) & & \\
(c) Vegetable based cropping & 26.548627 & 81.890609 \\
$\quad$ system (VBCS) & & \\
\hline 2. Plantation land & & \\
\hline (a) Mango orchard & 26.555395 & 81.845317 \\
(b) Bael orchard & 26.550175 & 81.844978 \\
(c) Ber orchard & 26.550350 & 81.845157 \\
(d) Aonla orchard & 26.549742 & 81.845457 \\
\hline 3. Forest land & & \\
\hline (a) Delbergia sisoo & 26.523968 & 81.844556 \\
(b) Eucalyptus spp. & 26.538073 & 81.840335 \\
(c) C. equesetifolia & 26.537708 & 81.837545 \\
(d) Tectona grandis & 26.537708 & 81.837545 \\
\hline 4. Barren land & & \\
\hline Site-I & 26.545131 & 81.837746 \\
Site-II & 26.540528 & 81.846340 \\
Site-III & 26.539717 & 81.844493 \\
Site-IV & 26.539228 & 81.843862 \\
\hline 5. Grass land & & \\
\hline Site-I & 26.537680 & 81.840933 \\
Site-II & 26.537677 & 81.841863 \\
Site-III & 26.537075 & 81.848535 \\
Site-IV & 26.537800 & 81.842305 \\
\hline
\end{tabular}

The samples collected from different spots in polythene bags, it was dried in shade condition. It was mixed and crushed with the help of mortar and pestle, then it was sieved with $0.02 \mathrm{~mm}$ sieves, and it is separated until it remains about $500 \mathrm{~g}$ only, then it was kept in a cool, dry and dark place in the laboratory. The samples were analyzed for different properties as per methods as enlisted below (Table 2).

Table 2: Soil analysis procedure

\begin{tabular}{ll}
\hline Physical properties & Methods adopted \\
\hline $\begin{array}{l}\text { Saturated Hydraulic } \\
\text { Conductivity }\left(\mathrm{cm} \mathrm{hr}^{-1}\right)\end{array}$ & Constant head method \\
Soil temperature $\left({ }^{\circ} \mathrm{C}\right)$ & Soil Thermometer \\
Bulk density $\left(\mathrm{Mg} \mathrm{m}^{-3}\right)$ & Core method (Black, 1955) \\
\hline
\end{tabular}




\section{RESULTS AND DISCUSSION}

Physical characteristics of cropland use presented in Table 3. The value of SHC were observed 0.22 $\mathrm{cm} \mathrm{hr}^{-1}$ in RWCS, $0.26 \mathrm{~cm} \mathrm{hr}^{-1}$ in LBCS and 0.24 $\mathrm{cm} \mathrm{hr}^{-1}$ in VBCS of cropland use. Its mean value calculated from observation is $0.24 \mathrm{~cm} \mathrm{hr}^{-1}$. Highest soil temperature recorded at $15 \mathrm{~cm}, 30 \mathrm{~cm}$ and $45 \mathrm{~cm}$ soil depth in VBCS $\left(33.0,32.0,31.5^{\circ} \mathrm{C}\right)$ followed by RWCS and LBCS in month of May and maximum soil temperature were recorded at $15 \mathrm{~cm}, 30 \mathrm{~cm}$ and $45 \mathrm{~cm}$ soil depth in RWCS $\left(14.0,15.0,16.0^{\circ} \mathrm{C}\right)$ in month of January. The bulk density in the month of July and January recorded maximum in RWCS $\left(1.32,1.35 \mathrm{Mg} \mathrm{m}^{-3}\right)$ followed by LBCS $(1.28,1.29 \mathrm{Mg}$ $\left.\mathrm{m}^{-3}\right)$ and $\operatorname{VBCS}\left(1.20,1.22 \mathrm{Mg} \mathrm{m}^{-3}\right)$.

The physical properties of forest land use are presented in Table 4 . The maximum SHC were recorded in Bael orchard $\left(0.21 \mathrm{~cm} \mathrm{hr}^{-1}\right)$ followed by Mango orchard $\left(0.16 \mathrm{~cm} \mathrm{hr}^{-1}\right)$, Ber orchard $(0.15 \mathrm{~cm}$ $\left.\mathrm{hr}^{-1}\right)$, Aonla orchard $\left(0.09 \mathrm{~cm} \mathrm{hr}^{-1}\right)$. The maximum soil temperature was observed at $15,30,45 \mathrm{~cm}$ soil depth in Aonla orchard $\left(40.5,39.0,38.0^{\circ} \mathrm{C}\right)$ in the month of May followed by Ber orchard, Bael orchard and
Mango orchard. The maximum soil temperature was observed at 15, 30, $45 \mathrm{~cm}$ soil depth in January is Mango orchard $\left(15.0,16.0,17.5 .0^{\circ} \mathrm{C}\right.$ ) followed by Bael orchard, Aonla orchard and Ber orchard. The maximum BD was observed in Bael orchard in the month of July (1.36 $\left.\mathrm{Mg} \mathrm{m}^{-3}\right)$ and January $(1.46 \mathrm{Mg}$ $\mathrm{m}^{-3}$ ) followed by Aonla orchard and Mango orchard.

The physical properties of forest land use are presented in Table 5. The maximum SHC were recorded in Eucalyptus spp. $\left(0.19 \mathrm{~cm} \mathrm{hr}^{-1}\right)$ followed by Dalbergia sissoo $\left(0.17 \mathrm{~cm} \mathrm{hr}^{-1}\right)$, Casuarina equsetifolia $\left(0.11 \mathrm{~cm} \mathrm{hr}^{-1}\right)$, Tectona grandis $\left(0.09 \mathrm{~cm} \mathrm{hr}^{-1}\right)$. The maximum soil temperature was observed at 15 , $30,45 \mathrm{~cm}$ soil depth in Tectona grandis (34.0, 33.5, $32.0^{\circ} \mathrm{C}$ ) in the month of May followed by Delbergia sissoo, Eucalyptus spp. and Casuarina equsetifolia. The maximum soil temperature was recorded at 15, 30, $45 \mathrm{~cm}$ soil depth in Eucalyptus spp. (13.0, $14.5,15.0^{\circ} \mathrm{C}$ ) in the month of January followed by Dalbergia sissoo, Tectona grandis and Casuarina equsetifolia. The maximum BD was observed in Tectona grandis in the month of July $\left(1.08 \mathrm{Mg} \mathrm{m}^{-3}\right)$ and January (1.09 $\mathrm{Mg} \mathrm{m}^{-3}$ ) followed by Eucalyptus spp., Delbergia sissoo and Casuarina equsetifolia.

Table 3: Physical characteristics of soil with crop land use

\begin{tabular}{|c|c|c|c|c|c|c|c|c|c|}
\hline \multirow{3}{*}{ Treatment } & \multirow{3}{*}{ SHC $\left(\mathrm{cm} \mathrm{hr} \mathbf{r}^{-1}\right)$} & \multicolumn{6}{|c|}{ Soil Temperature $\left({ }^{\circ} \mathrm{C}\right)$} & \multicolumn{2}{|c|}{ B.D. $\left(\mathrm{Mg} \mathrm{m}^{-3}\right)$} \\
\hline & & \multicolumn{3}{|c|}{ May } & \multicolumn{3}{|c|}{ January } & \multirow{2}{*}{ - July } & \multirow{2}{*}{ January } \\
\hline & & $15 \mathrm{~cm}$ & $30 \mathrm{~cm}$ & $45 \mathrm{~cm}$ & $15 \mathrm{~cm}$ & $30 \mathrm{~cm}$ & $45 \mathrm{~cm}$ & & \\
\hline (a) RWCS & 0.22 & 28.8 & 26.5 & 25.0 & 14.0 & 15.0 & 16.0 & 1.32 & 1.35 \\
\hline (b) LBCS & 0.26 & 27.5 & 27.0 & 26.5 & 13.5 & 14.0 & 15.0 & 1.28 & 1.29 \\
\hline (c) VBCS & 0.24 & 33.0 & 32.0 & 31.5 & 12.5 & 13.0 & 14.0 & 1.20 & 1.22 \\
\hline
\end{tabular}

Table 4: Physical characteristics of soil with plantation land use

\begin{tabular}{|c|c|c|c|c|c|c|c|c|c|}
\hline \multirow{3}{*}{ Treatment } & \multirow{3}{*}{$\begin{array}{l}\text { SHC } \\
\left(\mathrm{cm} \mathrm{hr}^{-1}\right)\end{array}$} & \multicolumn{6}{|c|}{ Soil Temperature $\left({ }^{\circ} \mathrm{C}\right)$} & \multicolumn{2}{|c|}{ B.D. $\left(\mathrm{Mg} \mathrm{m}^{-3}\right)$} \\
\hline & & \multicolumn{3}{|c|}{ May } & \multicolumn{3}{|c|}{ January } & \multirow{2}{*}{ - July } & \multirow{2}{*}{ January } \\
\hline & & $15 \mathrm{~cm}$ & $30 \mathrm{~cm}$ & $45 \mathrm{~cm}$ & $15 \mathrm{~cm}$ & $30 \mathrm{~cm}$ & $45 \mathrm{~cm}$ & & \\
\hline (a) Mango orchard & 0.16 & 31.0 & 30.5 & 30.0 & 15.0 & 16.0 & 17.5 & 1.02 & 1.00 \\
\hline (b) Bael orchard & 0.21 & 34.0 & 33.0 & 32.5 & 14.5 & 15.0 & 16.0 & 1.36 & 1.46 \\
\hline (c) Ber orchard & 0.15 & 41.0 & 40.5 & 39.0 & 13.5 & 14.0 & 15.0 & 1.24 & 1.27 \\
\hline (d) Aonla orchard & 0.09 & 40.5 & 39.0 & 38.0 & 14.0 & 15.0 & 16.5 & 1.30 & 1.33 \\
\hline
\end{tabular}

Table 5: Physical characteristics of soil with forest land use

\begin{tabular}{|c|c|c|c|c|c|c|c|c|c|}
\hline \multirow{3}{*}{ Treatment } & \multirow{3}{*}{$\begin{array}{l}\text { SHC } \\
\left(\mathrm{cm} \mathrm{hr}^{-1}\right)\end{array}$} & \multicolumn{6}{|c|}{ Soil Temperature $\left({ }^{\circ} \mathrm{C}\right)$} & \multicolumn{2}{|c|}{ B.D. $\left(\mathrm{Mg} \mathrm{m}^{-3}\right)$} \\
\hline & & \multicolumn{3}{|c|}{ May } & \multicolumn{3}{|c|}{ January } & \multirow{2}{*}{ July } & \multirow{2}{*}{ January } \\
\hline & & $15 \mathrm{~cm}$ & $30 \mathrm{~cm}$ & $45 \mathrm{~cm}$ & $15 \mathrm{~cm}$ & $30 \mathrm{~cm}$ & $45 \mathrm{~cm}$ & & \\
\hline (a) Delbergia sissoo & 0.17 & 33.0 & 32.0 & 31.5 & 13.0 & 14.0 & 15.0 & 1.02 & 1.06 \\
\hline (b) Eucalyptus sp. & 0.19 & 32.0 & 32.5 & 32.0 & 13.0 & 14.5 & 15.0 & 1.07 & 1.09 \\
\hline (c) C. equisetifolia & 0.11 & 30.0 & 29.5 & 29.0 & 12.0 & 12.5 & 13.0 & 1.00 & 1.08 \\
\hline (d) Tectona grandis & 0.09 & 34.0 & 33.5 & 32.0 & 13.0 & 14.0 & 15.0 & 1.08 & 1.09 \\
\hline
\end{tabular}


The physical properties of barren land use were presented in Table 6. The maximum SHC were recorded in barren land-IV $\left(0.06 \mathrm{~cm} \mathrm{hr}^{-1}\right)$ followed by barren land-III $\left(0.05 \mathrm{~cm} \mathrm{hr}^{-1}\right)$, barren land-I $\left(0.04 \mathrm{~cm} \mathrm{hr}^{-1}\right)$ and barren land-II $\left(0.02 \mathrm{~cm} \mathrm{hr}^{-1}\right)$. The maximum soil temperature was observed at 15, 30, $45 \mathrm{~cm}$ soil depth in barren land-I $\left(35.0,34.0,33.0^{\circ} \mathrm{C}\right)$ in the month of May followed by barren land-IV, barren land-II and barren land-III. The maximum soil temperature was observed at $15,30,45 \mathrm{~cm}$ soil depth in barren land-II $\left(14.5 .0,14.0,16.0{ }^{\circ} \mathrm{C}\right)$ in the month of January followed by barren land-I, barren land-III and barren land-IV. The maximum BD was observed in barren land-IV in the month of July $\left(1.50 \mathrm{Mg} \mathrm{m}^{-3}\right)$ and January $\left(1.52 \mathrm{Mg} \mathrm{m}^{-3}\right)$ followed by III, II and I location of barren land-III, II and I.

The physical properties of grassland use were presented in Table 7. The maximum SHC were recorded in grass land-I $\left(0.07 \mathrm{~cm} \mathrm{hr}^{-1}\right)$ followed by grass land-III $\left(0.06 \mathrm{~cm} \mathrm{hr}^{-1}\right)$, grass land-IV $(0.05 \mathrm{~cm}$ $\left.\mathrm{hr}^{-1}\right)$ and grass land-II $\left(0.03 \mathrm{~cm} \mathrm{hr}^{-1}\right)$. The maximum soil temperature was observed in grass land-I at 15, $30,45 \mathrm{~cm}$ soil depth in the month of May (35.0, 34.0, 33.5) followed by grass land-IV, grass land-III and grass land-II. The maximum soil temperature was observed in grass land-I at 15, 30, $45 \mathrm{~cm}$ soil depth in the month of January $(14.0,14.5,16.0)$ followed by grass land-III, grass land-II and grass land-IV. The maximum BD was observed in grass land-IV in the month of July (1.40 $\left.\mathrm{Mg} \mathrm{m}^{-3}\right)$ and January $(1.42 \mathrm{Mg}$ $\mathrm{m}^{-3}$ ) followed by III, II and I location of grassland.

The maximum value of saturated hydraulic conductivity (SHC) observed in cropland use, i.e. $0.24 \mathrm{~cm} / \mathrm{hr}$ followed by forest land $\left(0.16 \mathrm{~cm} \mathrm{hr}^{-1}\right)$ and plantation land $\left(0.15 \mathrm{~cm} \mathrm{hr}^{-1}\right)$. The minimum SHC were observed in barren land use $(0.04 \mathrm{~cm}$ $\mathrm{hr}^{-1}$ ). The higher SHC could be correlated with the good physical condition of cropland use. This result could be corroborated with findings of GoI (2009), who reported the different hydraulic conductivity of different land use.

At $15 \mathrm{~cm}$ soil depth maximum soil temperature was observed in plantation land $\left(36.6{ }^{\circ} \mathrm{C}\right)$ followed by grassland $\left(33.6^{\circ} \mathrm{C}\right)$, forest land $\left(32.2^{\circ} \mathrm{C}\right)$ and barren land $\left(30.3{ }^{\circ} \mathrm{C}\right)$. The minimum soil temperature was observed in cropland $\left(29.7^{\circ} \mathrm{C}\right)$. At $30 \mathrm{~cm}$ soil depth maximum soil temperature was observed in plantation land $\left(35.7^{\circ} \mathrm{C}\right)$ followed by grassland (33.6 $\left.{ }^{\circ} \mathrm{C}\right)$, forest land $\left(31.8^{\circ} \mathrm{C}\right)$ and barren land $\left(29.5^{\circ} \mathrm{C}\right)$. The minimum soil temperature was observed in cropland $\left(28.5^{\circ} \mathrm{C}\right)$. At $45 \mathrm{~cm}$ soil depth maximum soil temperature was observed in plantation land $\left(34.8^{\circ} \mathrm{C}\right)$ followed by grassland $\left(32.3^{\circ} \mathrm{C}\right)$, forest land $\left(31.1^{\circ} \mathrm{C}\right)$ and barren land $\left(28.8^{\circ} \mathrm{C}\right)$. The minimum soil temperature was observed in cropland (27.6 $\left.{ }^{\circ} \mathrm{C}\right)$ - soil temperature recorded in rabi season at $15 \mathrm{~cm}$ soil depth. The maximum soil temperature were observed in plantation land $\left(14.2^{\circ} \mathrm{C}\right)$ followed

Table 6: Physical characteristics of soil with barren land use

\begin{tabular}{|c|c|c|c|c|c|c|c|c|c|}
\hline \multirow{3}{*}{ Treatment } & \multirow{3}{*}{$\begin{array}{l}\text { SHC } \\
\left(\mathrm{cm} \mathrm{hr}^{-1}\right)\end{array}$} & \multicolumn{6}{|c|}{ Soil Temperature $\left({ }^{\circ} \mathrm{C}\right)$} & \multicolumn{2}{|c|}{ B D $\left(\mathrm{mg} \mathrm{m}^{-3}\right)$} \\
\hline & & \multicolumn{3}{|c|}{ May } & \multicolumn{3}{|c|}{ January } & \multirow{2}{*}{ July } & \multirow{2}{*}{ January } \\
\hline & & $15 \mathrm{~cm}$ & $30 \mathrm{~cm}$ & $45 \mathrm{~cm}$ & $15 \mathrm{~cm}$ & $30 \mathrm{~cm}$ & $45 \mathrm{~cm}$ & & \\
\hline BL-I & 0.04 & 35.0 & 34.0 & 33.0 & 14.0 & 15.0 & 14.0 & 1.39 & 1.42 \\
\hline $\mathrm{BL}-\mathrm{II}$ & 0.02 & 22.5 & 22.0 & 21.5 & 14.5 & 14.0 & 16.0 & 1.56 & 1.66 \\
\hline BL -III & 0.05 & 30.0 & 29.0 & 28.5 & 13.5 & 15.0 & 15.5 & 1.47 & 1.56 \\
\hline BL -IV & 0.06 & 34.0 & 33.0 & 32.5 & 12.5 & 13.0 & 13.0 & 1.50 & 1.52 \\
\hline
\end{tabular}

Table 7: Physical characteristics of soil with grass land use

\begin{tabular}{|c|c|c|c|c|c|c|c|c|c|}
\hline \multirow{3}{*}{ Treatment } & \multirow{3}{*}{$\begin{array}{l}\text { SHC } \\
\left(\mathrm{cm} \mathrm{hr}^{-1}\right)\end{array}$} & \multicolumn{6}{|c|}{ Soil Temperature $\left({ }^{\circ} \mathrm{C}\right)$} & \multicolumn{2}{|c|}{ B.D $\left(\mathrm{Mg} \mathrm{m}^{-3}\right)$} \\
\hline & & \multicolumn{3}{|c|}{ May } & \multicolumn{3}{|c|}{ January } & \multirow[t]{2}{*}{ July } & \multirow[t]{2}{*}{ January } \\
\hline & & $15 \mathrm{~cm}$ & $30 \mathrm{~cm}$ & $45 \mathrm{~cm}$ & $15 \mathrm{~cm}$ & $30 \mathrm{~cm}$ & $45 \mathrm{~cm}$ & & \\
\hline GL -I & 0.07 & 35.0 & 34.0 & 33.5 & 14.0 & 14.5 & 16.0 & 1.37 & 1.42 \\
\hline GL -II & 0.03 & 30.5 & 31.0 & 30.5 & 13.5 & 14.0 & 15.0 & 1.36 & 1.38 \\
\hline GL -III & 0.06 & 34.0 & 33.0 & 32.5 & 14.5 & 15.0 & 15.5 & 1.34 & 1.37 \\
\hline GL -IV & 0.05 & 35.0 & 34.0 & 33.0 & 12.5 & 13.5 & 14.0 & 1.40 & 1.42 \\
\hline
\end{tabular}


by barren land $\left(13.6{ }^{\circ} \mathrm{C}\right)$, grassland $\left(13.6{ }^{\circ} \mathrm{C}\right)$ and cropland $\left(13.3^{\circ} \mathrm{C}\right)$. The minimum soil temperature was observed in forest land $\left(12.7^{\circ} \mathrm{C}\right)$. At $30 \mathrm{~cm}$ soil depth maximum soil temperature was observed in plantation land $\left(15.0{ }^{\circ} \mathrm{C}\right)$ followed by barren land $\left(14.2^{\circ} \mathrm{C}\right)$, grassland $\left(14.2^{\circ} \mathrm{C}\right)$ and cropland $\left(14.0^{\circ} \mathrm{C}\right)$. The minimum soil temperature was observed in forest land $\left(13.7^{\circ} \mathrm{C}\right)$. At $45 \mathrm{~cm}$ soil depth maximum soil temperature was observed in plantation land $\left(16.2^{\circ} \mathrm{C}\right)$ followed by barren land $\left(15.3^{\circ} \mathrm{C}\right)$, grassland $\left(15.1^{\circ} \mathrm{C}\right)$ and cropland $\left(15.0^{\circ} \mathrm{C}\right)$. The minimum soil temperature was observed in forest land $\left(14.5^{\circ} \mathrm{C}\right)$. It may be because the plantation canopy increases the air temperature, which ultimately increases the soil temperature. Further plant canopy also preserved the soil temperature. The higher temperature in forest land can also be attributed to the above reasons. These results are in confirmatory with the findings of Hecht et al. (2008) and Nwankwo et al. (2012).

The maximum bulk density was observed of July in barren land $\left(1.48 \mathrm{Mg} \mathrm{m}^{-3}\right)$ followed by grassland $\left(1.36 \mathrm{Mg} \mathrm{m}^{-3}\right)$, cropland $\left(1.26 \mathrm{Mg} \mathrm{m}^{-3}\right)$ and plantation land $\left(1.23 \mathrm{Mg} \mathrm{m}^{-3}\right)$. The minimum bulk density was observed in forest land $\left(1.04 \mathrm{Mg} \mathrm{m}^{-3}\right)$. The maximum bulk density was observed of January in barren land $\left(1.54 \mathrm{Mg} \mathrm{m}^{-3}\right)$ followed by grassland $\left(1.39 \mathrm{Mg} \mathrm{m}^{-3}\right)$, cropland $\left(1.28 \mathrm{Mg} \mathrm{m}^{-3}\right)$ and plantation land $(1.26 \mathrm{Mg}$ $\left.\mathrm{m}^{-3}\right)$. The different land use especially plantation, varied in their ability to modify soil properties, especially nutrient status and bulk density. The results are in conformity with findings of Kar et al. (2021), Dutta et al. (2002), Roy et al. (2006) and GoI (2009).

\section{CONCLUSION}

Among cropland use legume-based cropping system was best in terms of saturated hydraulic conductivity, followed by bael orchard under plantation land use and Eucalyptus spp. under forest land use. Barren and the grass-based land use had the least saturated hydraulic conductivity. The soil temperature under different land use is decreased with increasing soil depth in May and increased with increasing depth in January. These soil properties were suited to plant for survival in large gap of temperature overall the year, i.e. about $10{ }^{\circ} \mathrm{C}$ to $36{ }^{\circ} \mathrm{C}$. The bulk density under all the different land use varied and it is was highest for barren land.

\section{REFERENCES}

1. Blake, G.R. 1965. Bulk density. In: Black, C.A. (ed.) Methods of Soil Analysis, Vol. 1. Madison: American Society of Agronomy, pp. 374-390

2. Dutta, R.K. and Agrawal, M. 2002. Effect of tree plantations on the soil characteristics and microbial activity of coal mine spoil land. Trop. Ecol., 43(2): 315-324.

3. Gol, C. 2009. Effects of land use change on soil properties and organic carbon at Dagdami river catchment in Turkey. J. Environ. Biol., 30(5): 825-230.

4. Hecht, B.P., Vogt, K.A., Eysteinsson, P. and Vogt, D.J. 2007. Changes in air and soil temperatures in three Icelandic birch forests with different land- use histories. Icel. Agric. Sci., 20: 49-60.

5. Kar, S., Pramanick, B., Brahmachari, K., Saha, G., Mahapatra, B.S., Saha, A. and Kumar, A. 2021. Exploring the best tillage option in rice based diversified cropping systems in alluvial soil of eastern India. Soil Tillage Res., 205: 104761.

6. Nwankwo, C. and Ogagarue, D. 2012. An Investigation of Temperature Variation at Soil Depths in Parts of Southern Nigeria. Am. J. Environ. Eng., 2(5): 142-147.

7. Roy, R., Mukhopadhyay, K. and Biswas, P. 2006. Soil aggregation and its relationship with physico-chemical properties under various lands use systems. Ind. J. Soil Conser., 34(1): 28-32. 
